\title{
PENGARUH MEGALITIK DI SITUS-SITUS PERTAHANAN TRADISIONAL MASA KOLONIAL AWAL DI MALUKU
}

\author{
Megalithic Influence on Traditional Defence Sites of \\ Colonial Period in Mollucas
}

\author{
Syahruddin Mansyur \\ Balai Arkeologi Ambon, Maluku, Indonesia \\ JI. Namalatu-Latuhalat, Ambon 97118 \\ hitam_putih07@yahoo.com
}

\begin{abstract}
This study was conducted at three sites; Bukit Amaiha, Bukit Wawani, and Bukit Kapahaha. These sites had correlation in settlement, traditional defense and megalithic sites. The result shows that the dolmen is a product of megalithic culture found on traditional defense sites on the island of Ambon. The influence on megalithic culture on traditional defense sites caused by the strong megaliths concept in the early colonial period in Maluku. Megalithic concept in Bukit largest Amaiha related to people effort to maintain the social status of their leader. On the other hand, it also related to their effort to gain cosmological legitimacy between leaders and community at Bukit Wawani.
\end{abstract}

Keywords: Maluku, Early Colonial Period, Megalithic, Dolmen.

\begin{abstract}
ABSTRAK
Penelitian ini dilakukan di tiga situs yaitu; situs Bukit Amaiha, situs Bukit Wawani, dan situs Bukit Kapahaha. Ketiga situs ini diduga memiliki korelasi antara situs pemukiman, situs pertahanan tradisional dan situs megalitik. Hasil penelitian menunjukkan bahwa batu meja adalah produk budaya megalitik yang banyak ditemui di situs-situs pertahanan tradisional di wilayah Pulau Ambon dan sekitarnya. Pengaruh megalitik pada situs-situs pertahanan tradisional yang ada di wilayah ini adalah karena masih kuatnya konsep megalitik pada masa kolonial awal di Maluku. Konsep megalitik di Situs Bukit Amaiha berkaitan dengan upaya untuk mempertahankan status sosial seorang pemimpin. Sementara itu, di situs Bukit Wawani berkaitan dengan upaya untuk memperoleh legitimasi kosmos antara pemimpin dan komunitasnya.
\end{abstract}

Kata Kunci: Maluku, Masa Kolonial Awal, Megalitik, Batu Meja.

Tanggal masuk : 17 Mei 2016

Tanggal diterima : 30 September 2016 


\section{PENDAHULUAN}

Kepulauan Maluku, secara geografis merupakan bagian dari sebuah kawasan yang disebut dengan Kepulauan Indo-Malaysia. Kawasan ini memiliki keragaman budaya tidak terbantahkan lagi, namun pertanyaan paling menarik adalah bagaimana menjelaskan proses keragaman budaya ini terjadi. Dalam rentang waktu yang panjang, salah satu penjelasan yang dikemukakan adalah akibat pengaruh yang berbeda-beda dari tradisi India, Islam, dan Eropa. Pendapat yang menarik dikemukakan oleh Bellwood (2000), bahwa keragaman itu disebabkan adanya proses ekspansi dan adaptasi yang berjalan lambat oleh suatu populasi etnolinguistik Austronesia awal yang relatif merupakan satu kesatuan. Keragaman ini kemudian dipadukan dengan hubungan antarkelompok dan pengaruh-pengaruh peradaban dari luar secara berurutan (Bellwood, 2000:187-188), termasuk tradisi India, Islam dan Eropa

Pengaruh awal populasi ethnolinguistik Austronesia di Kepulauan Maluku tampak pada sebaran jejak budaya neolitik dan megalitik di wilayah ini. Pengaruh budaya Neolitik tampak pada perkembangan teknologi alat kerang, teknologi pelayaran dan domestikasi hewan. Pengaruh budaya ini berkembang seiring adanya kontak-budaya antara masyarakat penutur bahasa Austronesia dengan komunitas NonAustronesia (Noerwidi, 2014: 8). Sementara itu, pengaruh budaya megalitik merupakan budaya atau tradisi yang dikaitkan dengan pemujaan terhadap arwah nenek moyang (Sukendar, 1993: 94). Dalam konteks pengaruh budaya, pemujaan terhadap arwah leluhur merupakan ciri masyarakat Austronesia yang tersebar luas (Bellwod, 2000: 205).

Pengaruh budaya megalitik di wilayah ini telah teridentifikasi sejak masa awal kedatangan bangsa Eropa di Maluku. Pengaruh budaya ini tampak pada catatancatatan bangsa Eropa tentang kondisi umum masyarakat pada masa-masa awal kedatangan bangsa Eropa di Maluku. Salah satunya ditulis oleh $\mathrm{J}$. Keuning yang tertuang dalam buku berjudul "Ambonnezen, Portugezeen, Nederlanders: Ambon's Geschiedenis tot het einde van de zeventiende eeuw". Sumber ini memberikan gambaran sistem religi masyarakat yang dipengaruhi oleh pemujaan terhadap arwah leluhur dan kepercayaan terhadap para dewa. Pusat aktivitas yang berhubungan dengan religi pada umumnya merupakan bangunan terbuka disebut Baileo, elemen lain adalah susunan batu yang menyerupai sebuah meja yang disebut batu mejal batu pamali, kedua elemen ini berfungsi sakral dan profan sebagai tempat melaksanakan upacara adat maupun pertemuan-pertemuan sosial (Keuning, tanpa tahun: 2 dan 11). Hingga saat ini, Baileo dan batu meja (dolmen) bagi masyarakat di Maluku merupakan elemen yang berfungsi sebagai tempat pelaksanaan ritual-ritual adat serta tempat dilaksanakannya perundingan-perundingan yang melibatkan perangkat adat.

$$
\text { Penelitian-penelitian awal }
$$
dalam konteks sebaran budaya megalitik di Maluku menunjukkan bahwa pengaruh megalitik tersebar luas di wilayah ini, khususnya di Pulau Seram dan Pulau Saparua. Karakter budaya megalitik yang umum dijumpai adalah dolmen atau 
dalam bahasa lokal disebut batu meja. Berdasarkan tradisi tutur masyarakat menyebutkan bahwa situs-situs megalitik yang umumnya berada di daerah perbukitan merupakan negeri lama (pemukiman kuno) leluhur mereka di masa lalu. Jika ditelusuri, sumber-sumber historis baik tekstual maupun pictorial, lokasi-lokasi yang saat ini diidentifikasi sebagai situs-situs megalitik diyakini memiliki korelasi dengan benteng pertahanan tradisional di wilayah Kepulauan Maluku. Sumber-sumber historis khususnya sumber pictorial sebagaimana dimuat dalam "Grote Atlas van de Verenigde OostIndische Compagnie deel 3 : Indische Archipel en Oceanie" memberi gambaran tentang lokasilokasi pertahanan tradisional masyarakat Maluku ketika menghadapi kehadiran bangsa Eropa (Roever.et.al, 2008). Lokasilokasi pertahanan tradisional yang dapat diidentifikasi memiliki korelasi dengan situs-situs megalitik diantaranya; bukit Amaiha di Iha (Pulau Saparua), bukit Wawani dan bukit Kapahaha (Pulau Ambon), bukit Hena Loi di Loki dan bukit Asaude (Pulau Seram).

Penelitian ini diarahkan untuk melakukan identifikasi awal terhadap situs-situs megalitik yang diyakini memiliki korelasi dengan benteng pertahanan tradisional di Maluku. Lebih lanjut, penelitian ini diharapkan mampu memberi gambaran tentang pengaruh budaya megalitik terhadap benteng pertahanan tradisional di Maluku yaitu Bukit Amaiha di Pulau Saparua, Bukit Wawani dan Bukit Kapahaha di Pulau Ambon. Penelitian ini tidak menjangkau situs-situs megalitik yang ada di Pulau Seram, namun tetap dibahas berdasarkan hasil-hasil penelitian sebelumnya.

Tiga pertanyaan penting dalam penelitian ini, adalah: pertama, jejak budaya materi apa saja yang dapat mengungkap korelasi antara situs-situs megalitik dengan benteng pertahanan tradisional di Maluku? ; kedua, bagaimana gambaran pengaruh budaya megalitik terhadap benteng pertahanan tradisional di Maluku? ; ketiga, mengapa pengaruh budaya megalitik masih bertahan hingga masa-masa awal kehadiran bangsa Eropa di Maluku?

\section{RUANG LINGKUP DAN METODE}

Fokus utama penelitian ini adalah untuk mengetahui korelasi antara situs-situs megalitik dengan benteng pertahanan tradisional di Maluku. Oleh karena itu, ruang lingkup data meliputi data arkeologi yaitu manifestasi jejak budaya megalitik di situs-situs pertahanan tradisional. Selain itu, data-data pendukung lain berupa data lingkungan dan data historis baik berupa tradisi lisan maupun data tekstual yang berkaitan dengan permasalahan penelitian.

Metode survei dan pengamatan diharapkan dapat merekam jejak budaya megalitik serta merekam sebanyak mungkin data di lokasi penelitian. Selain itu, metode wawancara diarahkan untuk menjaring informasi guna menjelaskan pengaruh budaya megalitik di situs-situs pertahanan tradisional. Demikian halnya metode tekskavasi atau menggali kedalaman teks yang diperoleh dari penelusuran sumber-sumber historis baik data tekstual maupun pictorial (Wibisono, 2013: 56). Metode ini diharapkan dapat memberi gambaran tentang kondisi awal benteng tradisional di 
Maluku pada masa-awal kehadiran bangsa Eropa di Maluku.

Selanjutnya, analisis deskriptif meliputi deskripsi verbal dan deskripsi pictorial untuk memberikan gambaran hasil pengumpulan data di lapangan. Selain itu, digunakan pendekatan analogi sejarah untuk mendukung data arkeologi dalam upaya rekonstruksi sejarah budaya (Sharer dan Ashmore, 1980: 445). Tahap akhir yaitu sintesa dan interpretasi data dilakukan dengan menggabungkan semua informasi untuk menjawab pertanyaanpertanyaan penelitian.

\section{RIWAYAT PENELITIAN SEBARAN BUDAYA MEGALITIK DI WILAYAH PULAU AMBON DAN SEKITARNYA}

Persebaran budaya megalitik di wilayah Maluku terekam dalam beberapa penelitian. Hasil-hasil penelitian ini berhasil menginventarisasi tinggalan budaya megalitik di beberapa lokasi di Pulau Saparua dan Pulau Seram. Hasilhasil inventarisasi ini menunjukkan bahwa temuan batu meja atau dolmen merupakan media upacara religi untuk menghormati arwah leluhur.

Sebaran situs megalitik di Pulau Saparua, terdapat di Bukit Huhule, Negeri/Desa Tuhaha Kecamatan Saparua. Di Bukit Huhule ini ditemukan lima buah batu meja yang berjejer dari arah utara ke selatan. Selain batu meja, di kompleks ini ditemukan pula batu menhir serta sebaran fragmen gerabah di sekitar lokasi situs tersebut (Salhuteru, 2008). Situs megalitik lainnya yang berhasil diidentifikasi terletak di Bukit Amaiha dengan keberadaan batu meja dan beberapa makam kuno (Sudarmika, 2000). Lokasi lain adalah di Bukit Elhau, Negeri/Desa Sirisori Islam, Kecamatan Saparua. Di Bukit Elhau ditemukan empat batu meja yang tersebar di areal situs tersebut, serta beberapa makam kuno serta bekas lokasi bangunan baileo. Di lokasi ini, baik makam-makam kuno maupun batu meja dipisahkan oleh susunan batu sehinga membentuk pemisahan ruang dalam kompleks situs. Temuan batu meja dan makam kuno juga berasosiasi dengan temuan lain berupa fragmen gerabah dan keramik asing (Mansyur, 2012).

Batu meja tidak hanya terdapat di daerah perbukitan, namun juga tersebar di setiap desa (pesisir) di Pulau Saparua, dan umumnya batu meja ditempatkan dekat baileo. Penempatan batu meja ini berkaitan dengan pelaksanaan upacara adat yang dilaksanakan di baileo, sehingga batu meja sering pula disebut sebagai batu pamali. Dengan demikian, terdapat dua pola sebaran lokasi keberadaan batu meja di wilayah Saparua, yaitu batu meja di daerah perbukitan dan batu meja di daerah pesisir (Salhuteru, 2008). 


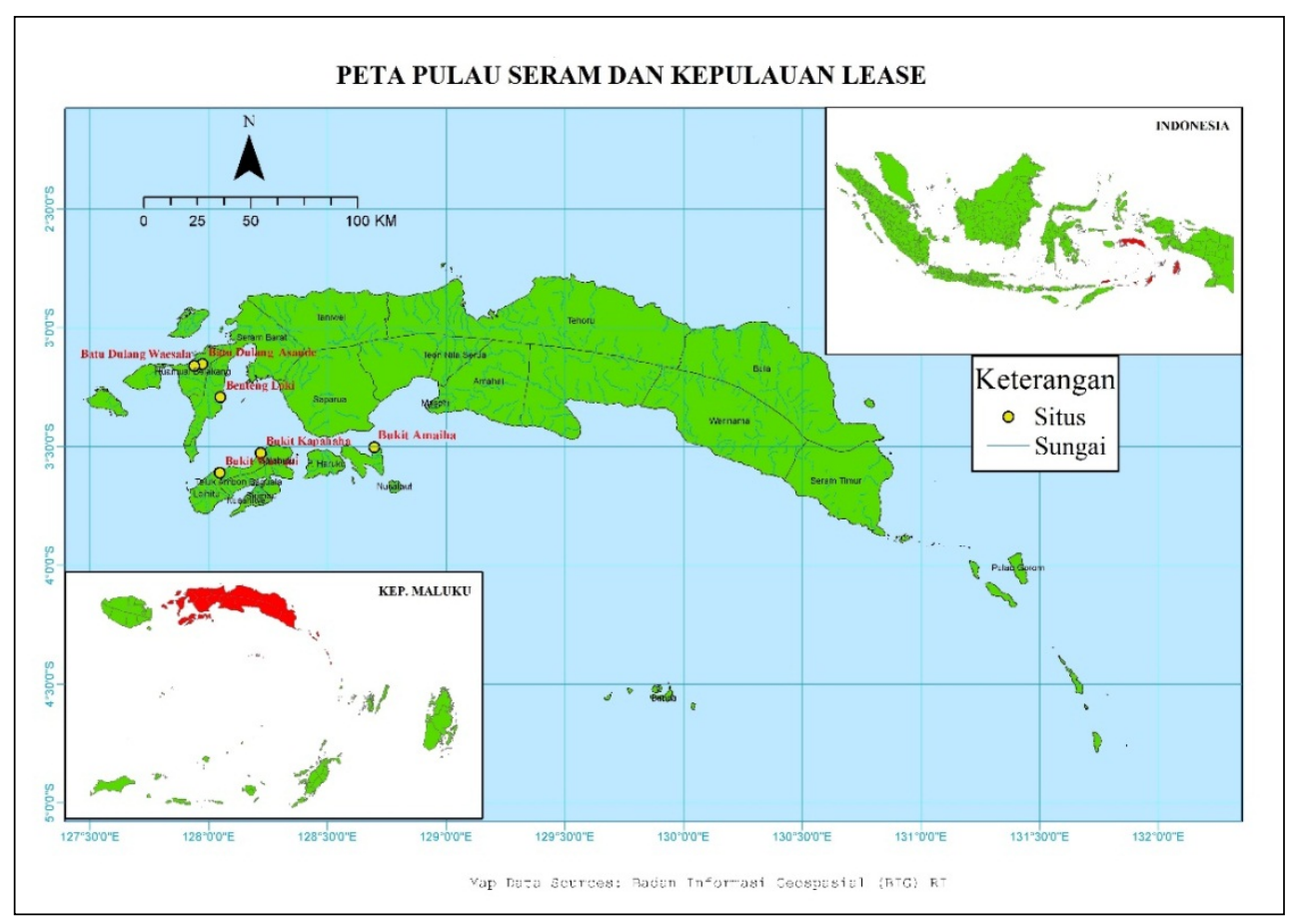

Gambar 1. Peta Sebaran Situs Megalitik di Wilayah Pulau Ambon dan Sekitarnya (Sumber: Peta dasar Badan Informasi Geospasial [BIG] dan dimodifikasi oleh Tim Pemetaan Balai Arkeologi Maluku, 2015)

Tinggalan megalitik tersebar di beberapa wilayah dan umumnya ditemui di daerah perbukitan di Pulau Seram. Temuan yang dominan adalah batu meja yang berasosiasi dengan temuan fragmen gerabah dan keramik asing, sehingga situs-situs megalitik ini diyakini sebagai situs pemukiman. Situs-situs megalitik di wilayah Pulau Seram tersebar di wilayah Seram bagian barat atau dikenal Jazirah Hoamoal, hingga ke wilayah timur bagian selatan. Batu meja ditemukan di situs Kota Mulu di Desa Wayasel yang terletak di Jazirah Hoamoal wilayah pesisir barat. Batu meja ini ditemukan berasosiasi dengan makam kuno Islam dan sebaran fragmen gerabah. Temuan berupa batu meja ini menyebar hingga ke utara yaitu situs batu dulang di Desa Waisala, dan situs hatulisa di Desa Asaude (Salhuteru, 2013). Situs lain dengan jejak budaya megalitik ditemukan di Negeri Lama Loki di bukit Hena Loi, yaitu satu buah batu meja dan menhir (Handoko, 2015: 403-404). Sebaran lain tinggalan megalitik di wilayah Seram barat ditemukan di Desa Kaibobo berupa batu meja dan batu keramat yang disebut mamori (Suryanto, 1997).

\section{PUSAT-PUSAT PERTAHANAN TRADISIONAL DALAM KONTEKS SEJARAH}

Situs-situs pertahanan tradisional didefinisikan sebagai lokasi pertahanan masyarakat lokal menjelang kehadiran bangsa Eropa di Maluku sekitar abad ke-16 dan 17. Periode awal kehadiran bangsa Eropa di Maluku tidak lepas dari upaya mereka menguasai perdagangan rempah-rempah khususnya cengkih dan pala di Kepulauan Maluku. Berbagai upaya 
ditempuh oleh bangsa Eropa khususnya Belanda melalui kongsi dagang VOC (Verenigdee Oostindische Compagnie), salah satunya adalah upaya penaklukan terhadap penduduk lokal Maluku yang saat itu telah membudidayakan tanaman cengkih sebagai komoditi perdagangan.

Sejak tahun 1620-an hingga tahun 1640-an, VOC melaksanakan ekspedisi penaklukan terhadap wilayah-wilayah produksi rempahrempah di Maluku, yaitu pusat produksi pala di Kepulauan Banda pada tahun 1620-an (Ricklefs, 2010), pusat-pusat produksi cengkih diantaranya; Pulau Saparua (Iha) pada tahun 1632 dan 1647 (Hitipieuw, 1984), Pulau Ambon (Hitu) pada tahun 1634, dan Pulau Seram (Hoamoal) sejak tahun 1605 hingga tahun 1652 (de Graaf, 1977). Keberhasilan atas penaklukan perlawanan lokal ini menjadi bagian sekaligus membuka jalan bagi pemusatan produksi cengkih di Kepulauan Lease dan menjadi titik awal bagi VOC untuk memperoleh keuntungan yang besar dalam perdagangan cengkih di Maluku.

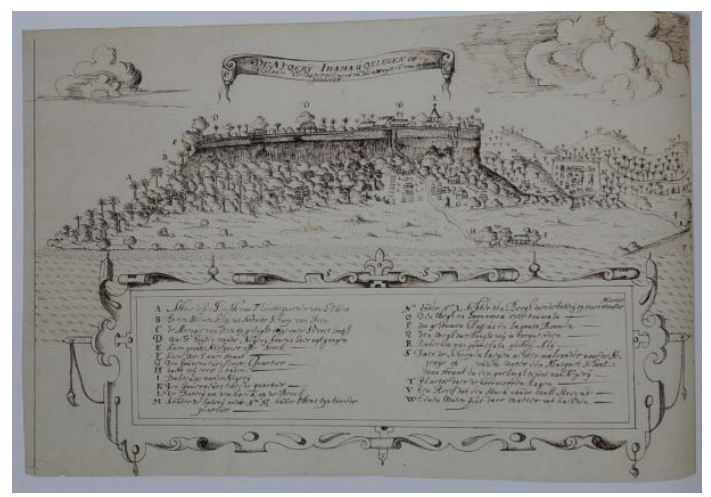

Gambar 2. Dokumentasi Kuno yang menggambarkan salah satu pusat pertahanan tradisional di Maluku tahun 1632 (Sumber: Roever.et.al, 2008)

Situs-situs pertahanan tradisional yang diduga memiliki hubungan dengan periode awal kehadiran VOC di wilayah Pulau Ambon dan sekitarnya, yaitu Iha di Pulau Saparua, Hitu di Pulau Ambon, dan Hoamoal di Pulau Seram. Dalam historiografi lokal, ketiga wilayah tersebut juga dikenal sebagai pusat-pusat kerajaan tradisional di Maluku yaitu Kerajaan Iha, Kerajaan Hitu, dan Kerajaan Homoal. Adapun pusat-pusat pertahanan yang ada, yaitu Bukit Amaiha di bekas Kerajaan Iha; Bukit Wawani dan Bukit Kapahaha di bekas Kerajaan Hitu; serta Kota Mulu (Wayasel), Bukit Asaude dan Bukit Henaloi (Loki) yang merupakan bagian dari bekas Kerajaan Hoamoal di Pulau Seram. Dalam catatan sejarah, pusat-pusat pertahanan tradisional tersebut terekam secara visual dalam catatan VOC dan dimuat dalam kumpulan dokumentasi tentang wilayah nusantara timur, yaitu buku "Grote Atlas van de Verenigde OostIndische Compagnie deel 3 : Indische Archipel en Oceanie".

\section{DESKRIPSI SITUS}

Secara administratif, lokasi situs yang menjadi bagian dari survei pada penelitian ini berada dalam wilayah adminstratif Kabupaten Maluku Tengah. Situs Bukit Amaiha berada di Negeri/Desa Iha dan Ihamahu, Kecamatan Saparua; dan Bukit Wawani dan Bukit Kapahaha yang berada di Kecamatan Leihitu Kabupaten Maluku Tengah.

\section{Bukit Amaiha}

Situs ini terletak pada sebuah daerah perbukitan yang berjarak \pm 600 meter dari garis pantai. Bukit Amaiha adalah sebuah bukit karang dengan kontur yang bertingkat, titik tertinggi pada bukit ini adalah \pm 125 mdpl. Kondisi lingkungan pada kaki bukit Amaiha di sebelah tenggara 
ditumbuhi oleh berbagai macam tanaman yaitu pada sisi paling bawah terdiri atas habitat pohon sagu, pada ketinggian selanjutnya adalah pohon pala, dan tanaman yang dominan pada sisi ketinggian yang mendekati puncak bukit adalah pohon pala dan pohon cengkih. Sementara itu, pada sisi puncak bukit ditumbuhi oleh berbagai tanaman perdu. Situs ini dapat dijangkau dari Negeri Ihamahu dengan menyusuri punggung bukit hingga akhirnya masuk melalui sisi tenggara situs Bukit Amaiha. Kondisi permukaan lahan pada situs ini didominasi oleh batuan karang dengan lapisan tanah yang tipis.

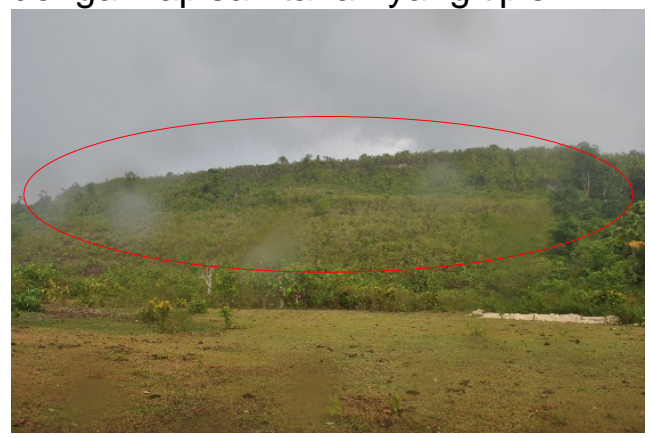

Gambar 3. Bentang Lahan Situs Bukit Amaiha (bandingkan dengan gambar 2). (Sumber: Dokumen Laporan Granucci Fund, 2015)
Menurut tradisi tutur masyarakat setempat, lokasi ini merupakan negeri lama atau pemukiman kuno masyarakat Iha sebelum direlokasi ke daerah pesisir. Masyarakat Ihamahu juga menyebut bukit ini sebagai bekas Kerajaan Iha. Informasi yang disampaikan oleh tokoh masyarakat bahwa bukit Amaiha adalah pusat Kerajaan Iha, dan ketika Kerajaan ini ditaklukan oleh VOC masyarakat Iha tercerai-berai. Beberapa diantaranya berpindah dan membentuk perkampungan di daerah lain yaitu Negeri Iha (dekat Negeri Luhu) yang ada di Seram Barat, sementara itu masyarakat yang bertahan di daerah ini membentuk dua perkampungan yaitu Negeri Iha (yang penduduknya menganut Islam) dan Negeri Ihamahu (yang penduduknya menganut Kristen). Akibat konflik sosial pada tahun 1999, masyarakat Negeri Iha di Pulau Saparua mengungsi dan membentuk perkampungan di Pulau Seram dekat Negeri Sepa (Dominggus Sopacua. Pers.comm., 7 Oktober 2015).

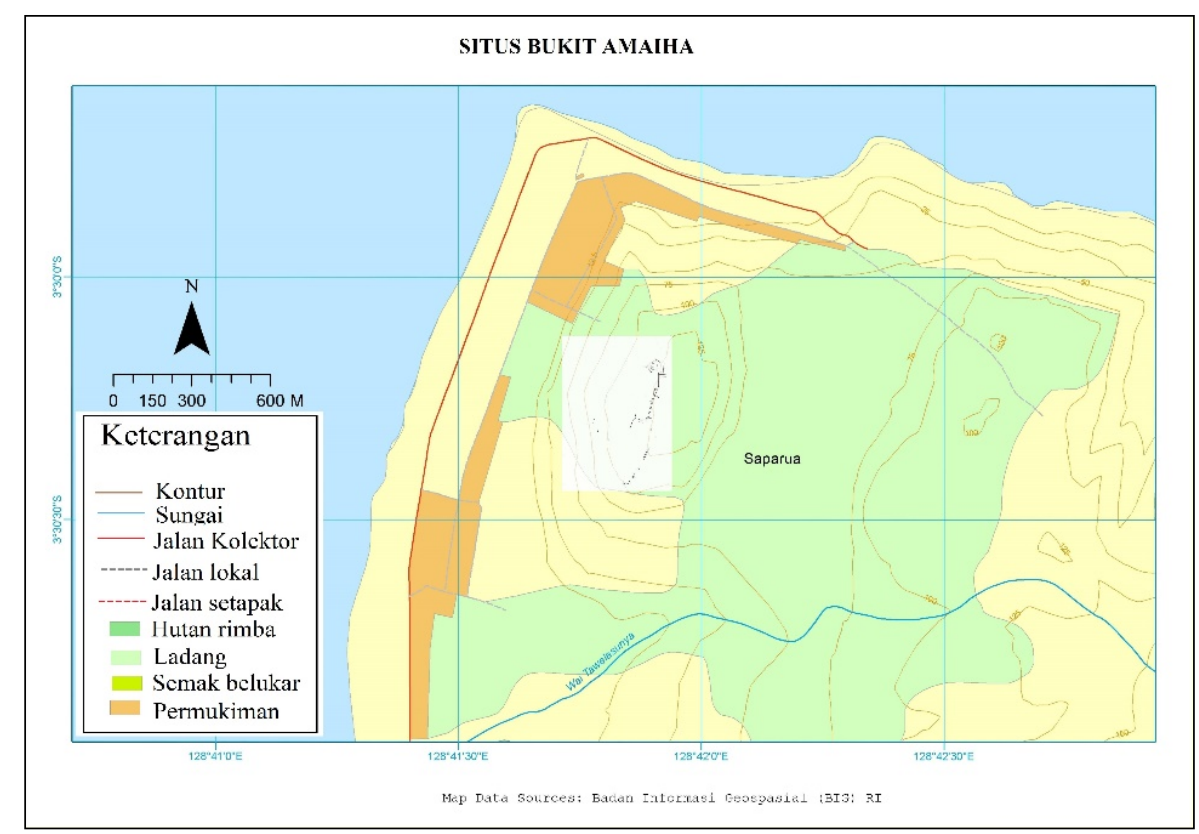

Gambar 4. Peta Situs Bukit Amaiha (Sumber: Peta Dasar BIG dan dimodifikasi untuk Dokumen Laporan Granucci Fund, 2015) 
Lokasi situs merupakan puncak tertinggi dari bukit Amaiha dengan bentang lahan atau permukaan tanah yang datar. Hasil survey di situs ini berupa bukti-bukti arkeologis seperti dua buah batu meja atau dolmen (Lebih lengkap dapat dilihat pada gambar 4 dan Gambar 9). Temuan lain adalah lima titik lokasi makam kuno (oleh masyarakat setempat disebut keramat). Terdapat pula tiga titik lokasi yang diyakini merupakan bekas lokasi bangunan yaitu Masjid Besar Iha, musholla, dan baileo (bangunan yang berfungsi sebagai tempat pertemuan adat). Pada titik lokasi bekas bangunan masjid dan musholla ditemukan masing-masing 3 fitur berupa lubang dengan

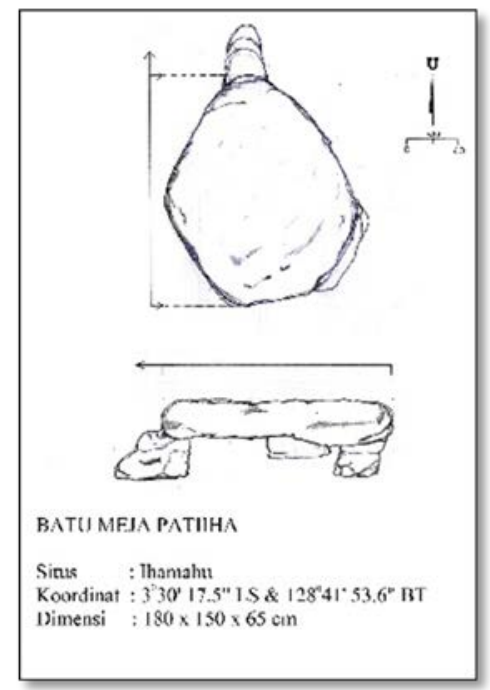

Gambar 5 dan 6. Temuan Struktur Batu Meja I dan Batu Meja II di Situs Bukit Amaiha (Sumber: Dokumen Laporan Granucci Fund, 2015)

kedalaman yang bervariasi. Dalam kompeks Bukit Amaiha ditemukan pula pagar atau susunan batu yang tampaknya menjadi pemisah antar ruang dalam kompleks situs. Jika mengamati kondisi lingkungan situs, susunan batu yang ada tampaknya menjadi batas pemisah kompleks situs Bukit Amaiha. Susunan batu

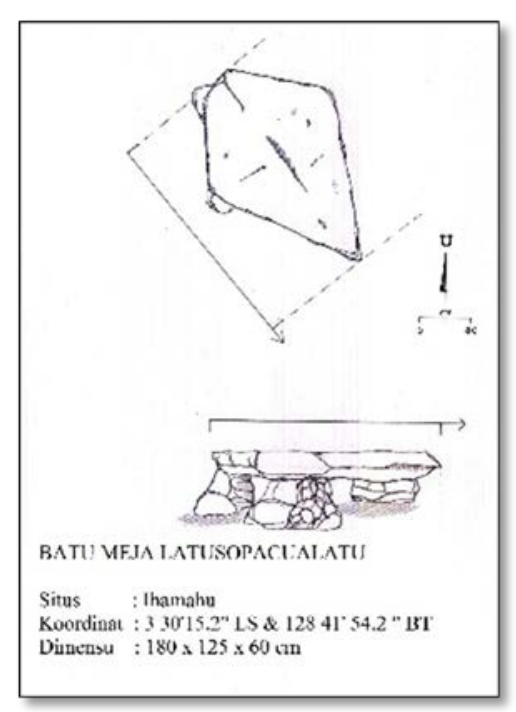

yang menjadi pemisah kompleks situs ini memanfaatkan kondisi lingkungan yang ada yaitu susunan batu dengan ketinggian $\pm 1,5$ meter ditempatkan pada lahan yang memiliki perbedaan kontur yang jelas (susunan batu ditempatkan di sisi ujung dari permukaan tanah yang lebih tinggi).

Temuan berupa batu meja terdapat di bagian tengah lokasi situs. Temuan batu meja di lokasi ini berupa lempengan batu berbentuk pipih (datar) berukuran besar yang ditopang oleh tiga bongkahan batu yang berfungsi sebagai kaki pada sisi bagian bawah. Lempengan pada Batu Meja I (Gambar 5) memiliki

bentuk persegi lima dengan diameter $150 \mathrm{~cm} \times 180 \mathrm{~cm}$ dan tebal $20 \mathrm{~cm}$, adapun ketinggian batu meja ini adalah $65 \mathrm{~cm}$. Jenis batuan dari batu meja ini adalah batu karang, dan hal ini dapat dilihat pada lempengan (sisi atas) maupun pada bagian kaki. Bapak Dominggus Sopacua menceritakan bahwa batu 
meja ini adalah batu meja milik marga Patiiha (marga ini sendiri saat ini menjabat sebagai Raja Ihamahu yaitu Bapak Agustinus Patiiha). Sementara itu, lempengan pada Batu Meja II (Gambar 6) memiliki bentuk persegi lima (menyerupai anak panah) dengan diameter 125 $\mathrm{cm} \times 180 \mathrm{~cm}$ dan tebal $25 \mathrm{~cm}$, adapun ketinggian batu meja ini adalah $60 \mathrm{~cm}$. Jenis batuan pada lempengan (sisi atas) adalah batu padas dan pada bagian kaki berupa jenis batu karang. Informan kami menyebutkan bahwa batu meja ini adalah batu meja milik marga Sopacua (marga ini sendiri saat ini menjabat sebagai Tua Negeri yaitu Bapak Dominggus Sopacua). Lokasi Batu Meja II berjarak \pm 30 meter arah utara dari Batu Meja I.

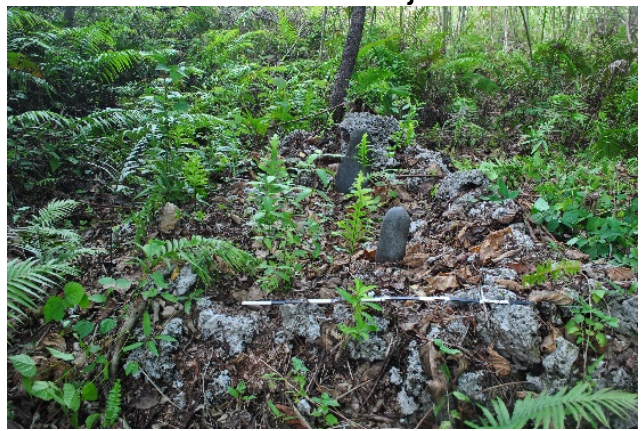

Gambar 7. Makam II di Lokasi Bekas Baileo di Situs Bukit Amaiha. Sumber: Dokumen Laporan Granucci Fund: 2015

Temuan lain berupa makam kuno ada di dalam kompleks situs. Secara umum makam kuno yang ditemui di situs ini memiliki bentuk yang sama yaitu terdiri dari batu karang disusun berbentuk persegi yang merupakan bagian jirat dan terdapat dua batu nisan pada bagian tengah makam Jika mengamati keletakan dua batu nisan yang ditempatkan pada arah utara dan selatan, tampak jelas bahwa orientasi makam ini adalah utaraselatan. Orientasi makam seperti ini umum ditemui pada makam-makam Islam. Makam Kuno I terdapat di sisi pintu masuk (tenggara) situs Bukit Amaiha. Ukuran pada jirat makam adalah $200 \mathrm{~cm} \times 120 \mathrm{~cm}$. Makam Kuno II berada di sebelah utara dari Batu Meja II dengan jarak \pm 200 meter, lokasi Makam Kuno II (Gambar 7) dekat dengan titik lokasi bekas bangunan baileo. Ukuran jirat pada makam ini adalah $210 \mathrm{~cm} \mathrm{x}$ $150 \mathrm{~cm}$. Makam Kuno III berada di sebelah barat dari titik lokasi bekas bangunan Musholla. Saat ini, Makam Kuno III hanya tinggal jirat tanpa nisan dengan ukuran jirat 230 cm x 165 cm. Makam Kuno IV

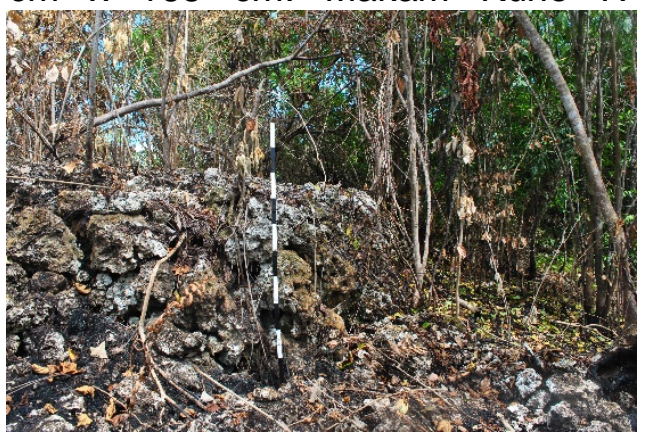

Gambar 8. Sisa Struktur Pondasi Masjid Situs Amaiha. Sumber: Dokumen Laporan Granucci Fund: 2015

berada di sebelah barat laut dari Makam III, makam Kuno IV ini memiliki ukuran yang lebih besar dari makam-makam yang lain yaitu $430 \mathrm{~cm} \times 250 \mathrm{~cm}$ serta tinggi $70 \mathrm{~cm}$. Makam Kuno $\mathrm{V}$ berada di sebelah utara Makam Kuno IV dengan jarak \pm 3 meter. Ukuran jirat pada makam ini adalah $250 \mathrm{~cm} \times 180 \mathrm{~cm}$ dengan tinggi $120 \mathrm{~cm}$. 


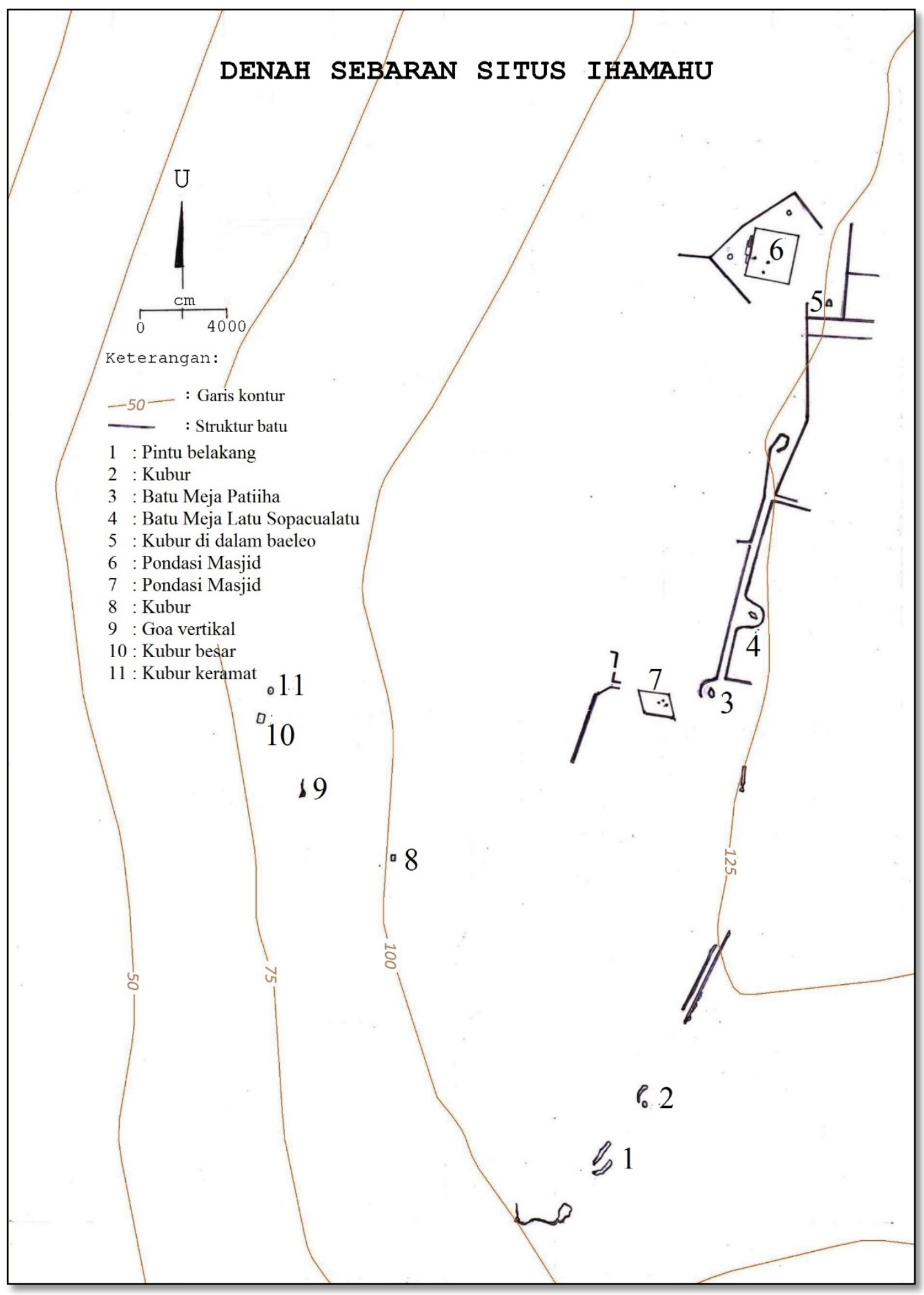

Gambar 9. Denah Sebaran Temuan di Situs Bukit Amaiha (Sumber: Dokumen Laporan Granucci Fund, 2015) 
Sementara itu, tiga titik lokasi bekas bangunan yang ditemui di situs Bukit Amaiha merupakan bekas pondasi bangunan masjid, musholla, dan baileo. Sisa pondasi yang ada saat ini terdiri dari batu karang yang disusun rapi dengan tinggi $80 \mathrm{~cm}$ sehingga lahan bekas bangunan masjid lebih tinggi dari lahan sekitarnya. Lokasi bekas bangunan masjid (Gambar 8) ini berada di sebelah utara Batu Meja II. Bekas pondasi masjid ini berbentuk persegi empat dengan ukuran $17 \mathrm{~m}$ x $19 \mathrm{~m}$. Pada lokasi bekas pondasi bangunan masjid terdapat tiga lubang dengan posisi keletakan berbentuk segitiga dengan diameter yang bervariasi antara $60 \mathrm{~cm}$ hingga $70 \mathrm{~cm}$, dan kedalaman yang bervariasi pula antara $40 \mathrm{~cm}$ hingga $85 \mathrm{~cm}$. Salah satu lubang yang terdapat di sisi timur ditemukan pecahan stoneware dengan ketebalan $1 \mathrm{~cm}$. Titik lokasi bangunan baileo berada di sebelah utara Batu Meja II. Saat ini, di lokasi bekas bangunan baileo hanya terdapat susunan batu karang yang membujur berbentuk persegi dan tampaknya merupakan pemisah ruang dengan lahan di sekitarnya. Sementara itu titik ketiga adalah lokasi bekas bangunan Mushalla yang berada di sebelah barat Batu Meja II, di lokasi ini juga ditemukan 3 lubang dengan posisi keletakan berbentuk segitiga. Lokasi ini berada pada kontur yang lebih tinggi dari lahan sekitarnya. Ukuran masingmasing lubang memiliki diameter bervariasi antara $30 \mathrm{~cm}$ hingga 50 $\mathrm{cm}$, dan kedalaman antara $30 \mathrm{~cm}$ hingga $50 \mathrm{~cm}$.

\section{Bukit Wawani dan Bukit Kapahaha \\ Situs Bukit Wawani berada di atas perbukitan pada kawasan Pegunungan Wawani. Situs ini}

berada pada posisi koordinat $\mathrm{S} 3^{0}$ 36' 39.5" dan E $128^{\circ}$ 02' 50.6" dengan ketinggian 482 mdpl. Lokasi situs ini dapat ditempuh dari Negeri Kaitetu maupun dari Negeri Seith, namun perjalanan dari Negeri Seith memiliki jarak dan waktu tempuh yang lebih mudah. Perjalanan menuju ke lokasi situs ditempuh dengan menyusuri punggung bukit hingga mencapai puncak Bukit Wawani. Kondisi lingkungan pada situs ini dari arah barat laut didominasi oleh vegetasi pohon pala dan cengkih. Selain itu terdapat vegetasi pohon sagu pada sisi kaki bukit yang dekat dengan puncak Bukit Wawani, dan tempat ini merupakan sumber air utama yang dialirkan menuju ke Negeri Seith yang ada di pesisir pantai.

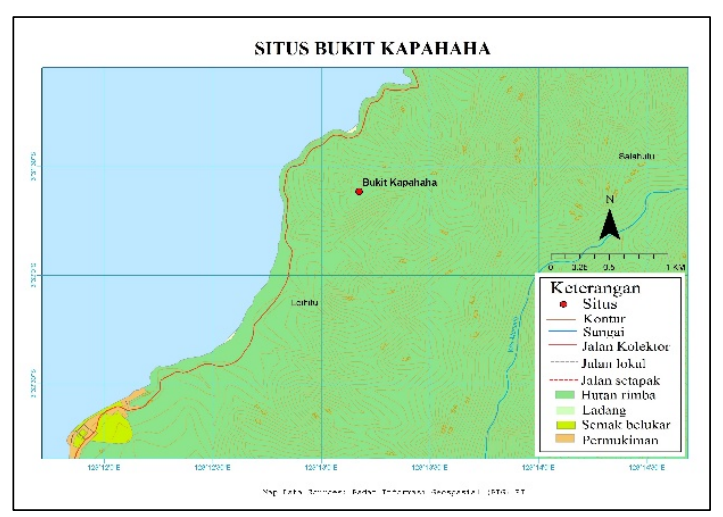

Gambar 10. Peta Situs Bukit Kapahaha (Sumber: Peta Dasar BIG dan dimodifikasi untuk Dokumen Laporan Granucci Fund, 2015))

Tradisi tutur setempat menyebut bahwa puncak Bukit Wawani adalah merupakan negeri lama masyarakat Negeri Kaitetu dan Negeri Seith sebelum berpindah ke daerah pesisir. Informasi yang disampaikan menyebut pula bahwa puncak Bukit Wawani adalah pusat pertahanan masyarakat lokal ketika menghadapi serangan VOC. Dalam historiografi lokal masyarakat Kaitetu dan Seith adalah bagian dari 
Kerajaan Hitu yang berkembang sekitar abad ke-17 (Djafar Lain, pers. comm., 12 Oktober 2015).

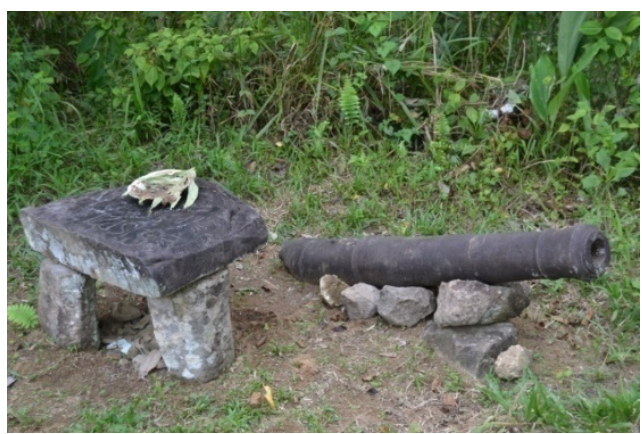

Gambar 11. Batu Meja yang berasosiasi dengan Meriam di Situs Bukit Wawani.

(Sumber: Dokumen Laporan Granucci Fund: 2015)

Lokasi situs merupakan puncak tertinggi dari bukit Wawani dengan bentang lahan atau permukaan tanah pada situs ini relatif datar. Lokasi puncak bukit ini sangat strategis karena dapat memantau wilayah sekitarnya terutama arah utara yang merupakan laut. Survey di situs ini menemukan bukti-bukti arkeologis berupa satu batu meja dan dua meriam Eropa, serta fragmen gerabah dan keramik asing. Informasi yang diperoleh menyebutkan bahwa lokasi keberadaan batu meja (Gambar 11) di Bukit Wawani merupakan tempat perundingan masyarakat Kaitetu. Sekitar abad ke-17, ketika Belanda mulai hadir di Pulau Ambon dan membangun benteng di wilayah pesisir, masyarakat Kaitetu yang bermukim di puncak bukit diminta turun ke pesisir untuk membuat perkampungan baru. Pemimpin masyarakat Kaitetu ketika itu bernama Latu Pau akhirnya berunding dengan masyarakat apakah tetap bermukim di puncak bukit atau memilih pindah ke wilayah pesisir (Husein Hatuwe, pers. comm., 14 Oktober 2015).

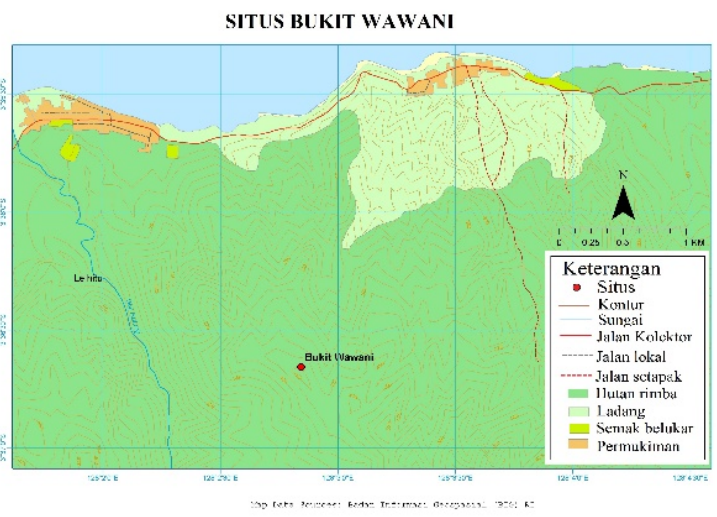

Gambar 12. Peta Situs Bukit Wawani (Sumber: Peta Dasar BIG dan dimodifikasi untuk Dokumen Granucci Fund, 2015)

Sementara itu, Situs Bukit Kapahaha berada di atas perbukitan pada kawasan pegunungan Salahutu. Situs ini berada pada posisi koordinat $S 3^{0} 31^{\prime} 48.9^{\prime \prime}$ dan E $128^{\circ} 12^{\prime}$ 47.3" dengan ketinggian 350 mdpl. Lokasi situs dapat ditempuh dari Negeri Morela dengan menyusuri jalan raya $\pm 1 \mathrm{~km}$ ke arah timur laut, dari titik ini perjalanan kemudian dilanjutkan dengan jalur pendakian. Kondisi lingkungan menuju ke arah lokasi situs didominasi oleh vegetasi pohon pala dan cengkih. Informasi masyarakat setempat menyebut bahwa lokasi situs Bukit Kapahaha adalah negeri lama masyarakat Negeri Morela dan Negeri Mamala, dan juga menjadi pusat pertahanan tradisional masyarakat lokal menghadapi kehadiran VOC di Pulau Ambon pada sekitar abad ke-17 (Abdullah Manilet, pers. comm., 17 Oktober 2015). 


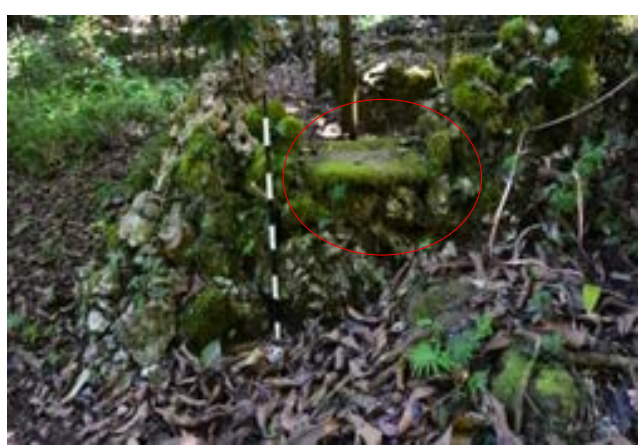

Gambar 13. Batu pipih pada gambar diduga bagian dari struktur batu meja, Situs Bukit Kapahaha. (Sumber: Dokumen Laporan Granucci Fund, 2015)

Lokasi situs merupakan dataran yang cukup luas, dan terdapat pada sebuah celah tebing sebagai pintu masuk ke kawasan situs Bukit Kapahaha. Temuan dominan di situs ini adalah lima makam kuno yang tersebar di dalam kawasan situs. Salah satu makam kuno (Gambar 13) di situs ini memiliki ukuran yang cukup besar berupa susunan batu berbentuk persegi yang oleh masyarakat setempat disebut Keramat Besar. Temuan berupa fragmen gerabah dan keramik juga ditemukan di sekitar kawasan situs. Selain itu, terdapat sumber air yang terletak di sebelah utara Keramat Besar. Temuan yang cukup menarik di lokasi ini adalah keberadaan sebuah batu berbentuk pipih dengan ukuran $60 \mathrm{~cm} \times 50 \mathrm{~cm}$ dengan ketebalan 10 $\mathrm{cm}$ yang ditempatkan di sisi pintu masuk Keramat Besar. Pada kedua sisi batu pipih tersebut juga ditempatkan masing-masing sebuah batu berbentuk lonjong. Ketiga batu ini diduga merupakan bagian dari batu meja yang sengaja ditempatkan di makam tersebut. Selain situs Bukit Kapahaha yang berada di atas bukit, titik lokasi lain berupa ceruk/gua berhasil diidentifikasi dengan adanya sebaran fragmen gerabah baik bagian depan maupun di bagian dalam ceruk. Titik lokasi ini berada di sisi bagian bawah yang berjarak \pm 2 $\mathrm{km}$ arah utara dari situs Bukit Kapahaha.

\section{DISKUSI}

\section{Korelasi Situs Pemukiman dan Situs Pertahanan}

Penelitian-penelitian

arkeologi yang telah dilakukan di wilayah Pulau Ambon dan sekitarnya, menunjukkan bahwa situs-situs pemukiman banyak ditemui di wilayah perbukitan. Situssitus pemukiman ini dipercaya oleh masyarakat sebagai lokasi pemukiman kuno yang sering disebut 'negeri lama'. Tipe pemukiman seperti ini jelas memanfaatkan kondisi alam setempat dimana wilayah ini terdiri atas pulau-pulau kecil dengan kontur yang rapat sehingga daerah perbukitan berada dekat dengan garis pantai. Faktor lain pemilihan tipe pemukiman seperti ini sekaligus mempertimbangkan aspek keamanan baik dari arah laut maupun dari darat. Selain aspek keamanan, pemilihan lokasi pemukiman tentu saja mempertimbangkan daya dukung lingkungan sebagai sumber bahan makanan baik akuatik maupun non akuatik. Survei yang dilakukan terhadap situs-situs pertahanan tradisional baik di Bukit Amaiha di Pulau Saparua, maupun Bukit Wawani dan Bukit Kapahaha di Pulau Ambon menunjukkan bahwa di masing-masing lokasi terdapat vegetasi pohon sagu sebagai sumber utama bahan makanan serta sumber air yang tidak jauh dari lokasi pemukiman. Dengan demikian, pemilihan wilayah perbukitan sebagai lokasi pemukiman memiliki hubungan 
antara pola pemukiman dan pola subsistensi.

Sumber-sumber historis menyebutkan bahwa pada periode awal kehadiran Bangsa Eropa di Maluku sekitar abad ke-16/17 M, pemukiman yang berada di atas perbukitan merupakan tipe pemukiman yang banyak ditemui di wilayah ini. Salah satu karya klasik tentang periode sejarah dunia timur yaitu "Suma Oriental" yang ditulis oleh Pires memberikan informasi bahwa orang-orang Banda membangun perkampungan mereka di pegunungan untuk menghindari bahaya yang kemungkinan datang dari arah laut (Cortesao, 1944: 293). Demikian halnya tulisan dari Valentijn yang berjudul "Oud en Nieuw Oost-Indien", menjelaskan bahwa perkampungan paling awal di Pulau Ternate adalah Tobona yang terletak di puncak gunung (Andaya, 1993). Sumber lain, dalam dokumen-dokumen VOC berupa sumber-sumber pictorial yang berasal dari abad ke-17 dimuat dalam "Grote Atlas van de Verenigde Oost-Indische Compagnie deel 3: Indische Archepel en Oceanie". Kumpulan sumber pictorial tersebut sangat jelas menggambarkan lokasi-lokasi perkampungan sekaligus pusatpusat pertahanan tradisional di Maluku berada di atas perbukitan (Roever, et.al, 2008).

Tipe pemukiman yang berada di wilayah perbukitan dengan ciri pertahanan yang kuat tampak jelas pada situs Bukit Amaiha, situs Bukit Wawani, dan situs Bukit Kapahaha. Situs Bukit Amaiha misalnya, berada di atas bukit karang yang terjal dan sulit dijangkau. Dokumen VOC bahkan memperlihatkan bahwa sekitar abad ke-17, Bukit Amaiha memiliki tembok pertahanan berupa susunan batu yang mengelilingi bukit ini. Meski saat ini, sisa-sisa tembok pertahanan yang mengelilingi bukit Amaiha tidak ditemukan lagi, namun hasil observasi menunjukkan bahwa ciri yang tampak pada situs ini adalah keberadaan susunan batu karang tanpa perekat yang diduga menjadi pemisah antar ruang dalam kompleks situs. Sumber historis juga memberi informasi bahwa penaklukan yang dilakukan oleh VOC pada tahun 1647 berhasil menghancurkan pusat pertahanan Bukit Amaiha dan merelokasi penduduk tha ke wilayah pesisir (Hitipiew, 1984). Situs lain yang memiliki karakter hampir sama dengan situs Bukit Amaiha adalah situs Bukit Elhau di Negeri Sirisori Islam di Pulau Saparua. Karakter situs ini adalah keberadaan susunan batu karang tanpa perekat yang mengelilingi areal situs; susunan batu karang yang tampak memisahkan antar ruang; keberadaan makam-makam kuno; serta keberadaan batu meja di dalam kompleks situs (Tim Penelitian, 2012).

Situs Bukit Wawani dan Bukit Kapahaha memiliki karakter bentang alam yang relatif sama dengan situs Bukit Amaiha. Meski lokasi situs berada cukup jauh dari garis pantai, namun dari titik lokasi masingmasing situs ini dapat memantau arah laut yang berada di sebelah utara. Kedua situs ini pun memiliki perbedaan bentang lahan, dimana situs Bukit Wawani lebih terjal sementara situs Bukit Kapahaha memiliki bentang lahan yang relatif datar. Dengan demikian, tampak jelas bahwa pemilihan lokasi situssitus ini mempertimbangkan aspek keamanan sehingga tetap memiliki ciri pertahanan yang kuat. Situs-situs lain yang memiliki karakter bentang lahan hampir sama dengan situs 
Bukit Wawani dan Bukit Kapahaha adalah situs Bukit Asaude dan situs Bukit Hena Loi (Loki) di Hoamoal (Seram Barat).

Data sejarah yang bersumber dari dokumen-dokumen VOC menyebutkan bahwa penaklukan terhadap pusat-pusat pertahanan tradisional di Pulau Ambon dan sekitarnya berlangsung sejak tahun 1605 hingga 1652. Penaklukan pusat-pusat pertahanan tradisional diiringi dengan relokasi penduduk ke wilayah pesisir, baik dekat pemukiman sebelumnya maupun ke tempat (pulau) lain (Hitipiew, 1984; de Graaf, 1977; Roever.et.al, 2008). Sumber ini tentu menjadi informasi penting bahwa pusat-pusat pemukiman (pertahanan) tradisional di wilayah Ambon dan sekitarnya telah ditinggalkan pasca penaklukan sekitar abad ke-17. Namun, data arkeologi memberi informasi tambahan bahwa pusat-pusat pemukiman ini tampaknya tetap dihuni pasca penaklukan, setidaknya sebagai hunian sementara. Hal ini dibuktikan pada penelitian-penelitian sebelumnya yang menemukan sebaran fragmen keramik asing di permukaan tanah di areal situs Bukit Wawani dan Bukit Kapahaha. Keramik-keramik ini diduga berasal dari cina abad ke-17 - 19 (Tim Penelitian, 2012). Hingga saat ini, permasalahan terkait penanggalan situs-situs megalitik di Indonesia masih menjadi perdebatan yang belum terpecahkan. Meski demikian, berdasarkan hasil radiokarbon situssitus megalitik di Indonesia khususnya di Sumatera, Sulawesi, Jawa, dan Bali diperoleh dua fase penanggalan yaitu fase pertama pada masa akhir prasejarah, dan fase kedua pada masa kehidupan sejarah (Prasetyo, 2015: 16).
Sementara itu, terkait kronologi hunian situs-situs megalitik yang memiliki korelasi dengan situs-situs pertahanan tradisional di wilayah Pulau Ambon dan sekitarnya dapat diketahui dengan melakukan perbandingan dengan hasil-hasil penelitian yang telah dilakukan sebelumnya. Hasil-hasil penelitian tersebut menjadi informasi penting yang dapat menjelaskan rentang hunian situs-situs pra-kolonial menjelang periode awal sejarah di Kepulauan Maluku.

Hasil penelitian Stark (1995)

misalnya, menyebutkan hasil analisis radiokarbon di situs Batususu (sebuah ceruk yang berada di kawasan Situs Bukit Kapahaha) menunjukkan kronologi sekitar 1100 - 1650 AD. (Stark and Latinis, 1996: 55; Kyle, 2004: 125). Situs lain adalah Situs Hatusua (sebuah situs pemukiman terbuka di wilayah pesisir selatan Seram bagian tengah), menunjukkan kronologi yang lebih tua yaitu sekitar 775 - $980 A D$, sementara itu kronologi lebih muda pada situs ini tampak pada temuan keramik asing yang berasal dari abad ke-14 -16 M (Kyle, 2004: 163). Demikian halnya penelitian yang dilakukan oleh Lape (2000), di Kepulauan Banda (sebelah tenggara Pulau Ambon) menunjukkan tiga fase hunian di wilayah ini, yaitu: 500 - $1000 A D$; 1000 - $1400 A D ;$ dan $1409-1625$ $A D$ (Lape, 2000; Lape, 2002: 59). Demikian halnya hasil pertanggalan baru di situs-situs hunian di Pulau Banda menunjukkan kronologi sekitar 981 - 1385 BP (Peterson, 2015: 92).

\section{Konsep Megalitik Situs-Situs Pertahanan Tradisional \\ Batu Meja adalah jejak} budaya megalitik yang ditemui di hampir semua situs-situs 
pemukiman kuno atau negeri lama di wilayah Pulau Ambon dan sekitarnya. Pada umumnya, batu meja merupakan batu pipih berbentuk persegi atau bulat dengan tiga batu yang berfungsi sebagai kaki atau penopang. Informasi yang diperoleh dari masyarakat setempat menyebutkan batu meja berfungsi sakral sebagai media penghormatan terhadapat leluhur. Penempatan batu meja di tengah-tengah pemukiman menunjukkan bahwa budaya materi ini menjadi elemen utama yang membentuk karakter pola pemukiman.

Dalam konteks jejak materi budaya megalitik, Bellwood (2000), dengan mencontohkan tradisi masyarakat Nias di Sumatera menjelaskan bahwa dorongan utama penciptaan bangunan-bangunan megalitik dalam budaya berciri Austronesia berkaitan erat dengan status sosial. Struktur-struktur megalitik dalam berbagai bentuk diciptakan untuk mencapai status pemimpin, baik ketika masih hidup maupun sesudah mati (Bellwood, 2000). Hal ini tampak jelas di Bukit Amaiha, dimana pemberian nama batu meja berhubungan dengan marga tertentu yang berstatus raja (status pemimpin dalam komunitas setingkat kampung/desa). Sumber sejarah menyebutkan bahwa marga Latusopacualatu adalah marga yang berkedudukan sebagai raja ketika penaklukan Iha pada abad ke-17 (Hitipieuw, 1984). Demikian halnya saat ini, marga Sopacua dan Patiiha (sesuai dengan nama kedua batu meja yang terdapat di Bukit Amaiha) memiliki status sosial yang tinggi dalam masyarakat di Negeri Ihamahu, yaitu marga Sopacua sebagai tua negeri / opu (pelaksana adat) dan marga Patiiha sebagai raja (pelaksana pemerintahan). Selain masyarakat Negeri Ihamahu yang berada di sisi selatan bukit Amaiha, masyarakat Negeri Noloth yang berada di sisi utara juga masih sering mengadakan upacara adat dengan melantunkan kapata (nyanyian rakyat yang berisi penuturan kisah atau peristiwa) Gunung Iha sebagai bagian ritual pemanggilan arwah leluhur yang berada di Bukit Amaiha (Latupapua. dkk, 2012: 38-39)

Sementara itu, batu meja yang terdapat di Bukit Wawani menjadi penanda yang sakral bagi masyarakat Kaitetu di masa lalu. Penanda sakral ini tampak jelas ketika mereka melakukan perundingan di lokasi batu meja untuk memutuskan membentuk pemukiman baru di wilayah pesisir. Dalam kosmologi masyarakat tradisional di masa lalu, keputusan untuk berpindah ke lokasi pemukiman baru tidak diputuskan begitu saja. Keputusan ini harus dirundingkan bersama di tempat yang dianggap sakral. Hal ini dimaksudkan agar keputusan apapun yang diambil adalah keputusan terbaik dan mendapat restu dari leluhur mereka. Selain itu, pilihan lokasi perundingan di tempat sakral dimaksudkan agar masyarakat yang ikut dalam perundingan tetap patuh pada pilihan yang telah diputuskan. Dengan demikian, keputusan yang diambil mendapat legitimasi dari para leluhur (dalam konsep kosmologi) serta mendapat legitimasi dari anggota masyarakat.

Praktek-praktek

sebagaimana tersebut di atas masih berlangsung pada tradisi masyarakat di wilayah tersebut. Karakter umum pola pemukiman yang saat ini berada di wilayah pesisir selalu menempatkan batu meja dan baileo yang saling berdekatan. Baileo bagi masyarakat di Maluku merupakan 
bangunan yang berfungsi sebagai tempat pelaksanaan ritual-ritual adat serta tempat dilaksanakannya perundingan-perundingan yang melibatkan perangkat adat. Salah satu contoh ritual yang dilaksanakan di baileo adalah upacara pelantikan raja. Dalam ritual ini, batu meja menjadi salah satu bagian dari upacara pengukuhan raja (Handoko, 2015: 381-382).

\section{PENUTUP}

Penulusuran awal sumbersumber historis memberi informasi tentang lokasi-lokasi yang berhubungan dengan benteng pertahanan pada periode awal kehadiran kolonial (Eropa) di wilayah pulau Ambon dan sekitarnya. Lokasi-lokasi ini diantaranya, bukit Amaiha, bukit Wawani, dan bukit Kapahaha. Tidak hanya berfungsi sebagai benteng pertahanan, survey yang dilakukan menunjukkan bahwa ketiga situs tersebut sekaligus merupakan lokasi permukiman kuno. Data arkeologi yang mengindikasikan hal ini, diantaranya; batu meja, bekas pondasi masjid dan baileo, makam-makam kuno, serta temuan berupa fragmen gerabah dan keramik. Keberadaan batu meja sebagai elemen utama ketiga situs tersebut memberi pemahaman bahwa lokasi-lokasi pertahanan tradisional di Maluku memiliki korelasi yang kuat dengan budaya megalitik.

Gambaran budaya megalitik pada situs-situs ini tampak pada penciptaan sarana pemujaan dan penghormatan arwah leluhur. Pengaruh budaya megalitik dapat dilihat di situs Bukit Amaiha yang berkaitan dengan upaya untuk mempertahankan status sosial seorang pemimpin. Sementara itu, di situs Bukit Wawani berkaitan dengan upaya untuk memperoleh legitimasi kosmos antara pemimpin dan komunitasnya.

$$
\text { Keberadaan bukti-bukti }
$$

budaya megalitik di situs-situs pertahanan tradisional di Pulau Ambon dan sekitarnya menunjukkan bahwa tradisi ini masih sangat kuat pada masa kolonial awal di Maluku. Praktek-praktek tradisi megalitik ini bahkan masih bertahan hingga masa kini. Hal ini memberi pemahaman kepada kita bahwa proses ekspansi atau hadirnya pengaruh-pengaruh peradaban dari luar tidak serta merta dapat mengubah konsepsi kosmologi yang telah mereka pahami jauh sebelumnya. Dengan demikian, pemahaman ini menjadi salah satu contoh yang tepat atas penjelasan keberagaman budaya di wilayah sebaran pengaruh Austronesia. Sebagaimana dijelaskan oleh Peter Bellwood bahwa keragaman itu disebabkan adanya proses ekspansi dan adaptasi yang lambat atas hadirnya pengaruh dari luar secara berurutan.

\section{UCAPAN TERIMA KASIH}

Draft awal naskah ini merupakan Laporan Hasil Penelitian yang didanai oleh Granucci Fund pada tahun 2015. Untuk itu, penulis mengucapkan terima kasih sebesarbesarnya kepada Anthony $F$. Granucci yang telah mendanai penelitian ini, serta Prof. Peter Bellwood (IPPA) yang mengorganisir pendanaannya. Terima kasih secara khusus saya ucapkan kepada Drs. Muhammad Husni, MM selaku Kepala Balai Arkeologi Ambon, Camat Saparua, dan Camat Leihitu, yang telah memberi izin untuk melaksanakan penelitian ini. Terima kasih pula kepada Bapak Dominggus Sopacua, Bapak Djafar 
Lain, Bapak Husein Hatuwe, dan Bapak Abdullah Manilet yang telah bersedia menjadi informan penelitian ini. Laporan penelitian ini tidak akan dilengkapi dengan berbagai ilustrasi baik peta maupun gambar tanpa bantuan dari Muhammad Al Mujabuda'wat, S.Hum. 
Andaya, Y. Leonard. 1993. The World of Maluku: Eastern Indonesia in the Early Modern Period. Honolulu:University of Hawaii Press.

Bellwood, Peter. 2000. Prasejarah Kepulauan Indo-Malaysia. Edisi Revisi. Terjemahan dari Judul Asli: Prehistory of the Indo-Malaysia Archipelago. Penerjemah: T.W. Kamil. Jakarta: PT. Gramedia Pustaka Utama.

Cortesao, Armando. 1944. Suma Oriental: Karya Tome Pires: Perjalanan dari Laut Merah ke Cina dan Buku Francisco Rodrigues. Edisi Terjemahan (2015) dari Judul Asli: The Suma Oriental of Tome Pires An Account of The East, From The Sea to China and The Book of Francisco Rodrigues. Penerjemah: Adrian Perkasa dan Anggita Pramesti. Yogyakarta: Penerbit Ombak.

de Graaf., H.J. 1977. Sejarah Ambon dan Maluku Selatan. Terjemahan dari Judul Asli: Geschiedenis van Ambon en de Zuid Molukken. Diterjemahkan oleh Frans Rijoly. Tanpa penerbit

Handoko, W. 2015. "Kearifan Budaya dan Keberlanjutan Religi Megalitik Pulau Seram Provinsi Maluku". Pernak-Pernik Megalitik Nusantara. Bagyo Prasetyo dan Nurhadi Rangkuti, ed. Jogjakarta: Galang Press

Hitipeuw, Frans. 1984. Kerajaan Iha Berinteraksi dengan Segala Suku Bangsa di Abad XVII dalam Perjuangan Nasional. Jakarta: Departemen Pendidikan dan Kebudayaan, Direktorat Sejarah dan Nilai Tradisional, Proyek Inventarisasi dan Dokumentasi Sejarah Nasional.

Keuning, J., tanpa tahun. Orang Ambon, Portugis dan Belanda: Sejarah Ambon sampai akhir abad ke-17. Terjemahan dari Judul Asli: Ambonnezen, Portugezeen, Nederlanders: Ambon's Geschiedenis tot het einde van de zeventiende eeuw. Penerjemah Frans Rijoly. Tanpa penerbit

Lape, Peter. 2000. "Contact and Conflict in The Banda Islands, Eastern Indonesia 11th-17th Centuries". Ph.D dissertation, Brown University, Rhode Island.

. 2002. "Historic Maps and Archaeology as a Means of Understanding Late Precolonial Settlement in the Banda Islands, Indonesia". Asian Perspectives, 41 (1): 43-70. University of Hawai'i Press.

Latinis, D. K. 2004. "Protohistoric Archaeology and Settlement in Central Maluku, Eastern Indonesi"a. Ph.D Dissertation, Department of Southeast Asian Studies Programme, National University of Singapore.

Latupapua, F.E. dkk., 2012. Kapata: Sastra Lisan di Maluku Tengah. Ambon: Balai Pengkajian Nilai Budaya Provinsi Maluku dan Maluku Utara. 
Leirissa, R.Z., et.al. 1973. Bunga Rampai Sejarah Maluku. Jakarta: Lembaga Penelitian Sejarah Maluku.

Mansyur, Syahruddin. 2012. Laporan Penelitian Arkeologi: Dinamika Pengaruh Kolonial di Pesisir Utara Pulau Ambon. Ambon: Balai Arkeologi Ambon.

Mansyur, Syahruddin, 2012. Laporan Penelitian Arkeologi: Studi Konseptual Museum Negeri Sirisori Islam. Kecamatan Saparua, Kabupaten Maluku Tengah. Ambon: Balai Arkeologi Ambon.

Noerwidi, Sofwan. 2014. "Migrasi Austronesia dan Implikasinya Terhadap Perkembangan Budaya di Kepulauan Indonesia". Amerta: Jurnal Penelitian dan Pengembangan Arkeologi. ISSN 0125-1324, Akreditasi LIPI No. 395/D/2012. Hal. 1-10 . Jakarta: Pusat Arkeologi Nasional.

Peterson, E.J. 2015. "Insularity and Adaptation: Investigation the Role of Exchange and Inter-Island Interaction in the Banda Islands, Indonesia". Ph.D Dissertation, University of Washington.

Prasetyo, B. 2015. "Prolog". Pernak-Pernik Megalitik Nusantara. Bagyo Prasetyo dan Nurhadi Rangkuti, ed. Jogjakarta: Galang Press

Ricklefs, 2010. Sejarah Indonesia Modern: 1200-2008, Cetakan III November 2010. Jakarta: Serambi Ilmu Semesta.

Roever, A.de. et.al. 2008. Grote Atlas van de Verenigde Oost-Indische Compagnie deel 3: Indisvhe Archipel en Oceanie. Zierikzee: Asia Maior.

Salhuteru, Marlyn, 2008. Laporan Penelitian Arkeologi: Pola Sebaran Tinggalan Megalitik di Desa Tuhaha, Kecamatan Saparua, Kabupaten Maluku Tengah. Ambon: Balai Arkeologi Ambon.

Salhuteru, Marlyn, 2013. Laporan Penelitian Arkeologi: Survey Arkeologi di Wilayah Kecamatan Waysala, Kabupaten Seram Bagian Barat. Ambon: Balai Arkeologi Ambon.

Stark, Ken., and Latinis, Kyle. 1996. "The Response of Early Ambonese Foragers to The Maluku Spice Trade: The Archaeological Evidence". Cakalele 7:51-67.

Sudarmika. G.M. 2000. Laporan Penelitian Arkeologi: Survey Arkeologi di Pulau Saparua, Maluku Tengah. Ambon: Balai Arkeologi Ambon.

Sukendar, Haris. 1993. "Arca Menhir Di Indonesia : Fungsinya Dalam Peribadatan". Disertasi. Program Pascasarjana. Universitas Indonesia.

Suryanto, Diman. 1997. Laporan Penelitian Arkeologi: Survey Potensi Kepurbakalaan di Wilayah Kaibobo Pulau Seram. Ambon: Balai Arkeologi Ambon. 
Wibisono, Sony. 2013. "Irigasi Tirtayasa: Teknik Pengelolaan Air Kesultanan Banten pada Abad ke-17". Amerta: Jurnal Penelitian dan Pengembangan Arkeologi. ISSN 0125-1324, Akreditasi LIPI No. 395/D/2012. Hal. 53-68 . Jakarta: Pusat Arkeologi Nasional 